\title{
Evaluation of risk factors for mortality in hematological malignancy patients admitted to intensive care unit
}

\author{
I leri $^{1^{*}}, \mathrm{R}$ Coskun², K Gundogan², M Guven², M Sungur ${ }^{2}$ \\ From ESICM LIVES 2015 \\ Berlin, Germany. 3-7 October 2015
}

\begin{abstract}
Intr
Haematological malignancies are associated with treatment releated morbidity and mortality. Intensive chemotherapy and haematopoetic stem cell transplantation has increased treatment releated complications. Transferring a severely ill patients to the intensive care unit for life support is often a difficult decision.
\end{abstract}

\section{Objectives}

To detect risk factors effecting haematological malignancy patients mortality after admission to the medical intensive care unit.

\section{Methods}

This study was performed prospectively in the medical intensive care unit of Erciyes Universty Hospital. History, physical exam and laboratory findings on admisssion, and therapeutic interventions during ICU stay were recorded. The study end point was ICU mortality.

\section{Results}

$32(\% 60)$ of the 53 patients included into this study were male. The average age of the patients was $49 \pm 19$ years. The hematological diagnosis of the patients were as follows; 19 were AML, 12 were MM, 7 were Non-Hodgin Lymphoma and 6were ALL. The most common reasons for ICU admissions were respiratory failure (\%57) and septic shock (\%17). The mean time delay starting from deteriation to ICU was 6 hours (range 1-48). APACHE-2 score was $26 \pm 8$ and the early warning system score was 8 (range 1-14). APACHE-2 score and time delay for ICU admission of nonsurvivors were higher $(\mathrm{p}=0.009,0.05$

${ }^{1}$ Erciyes University Faculty of Medicine, Internal Medicine, Kayseri, Turkey Full list of author information is available at the end of the article respectively). Serum total cortisol levels were lower in survivors compared to nonsurvivors $(\mathrm{p}=0.023)$. ICU mortality rate was $60 \%$.

\section{Conclusions}

The mortality rate of haematological malignancy patients rate was high. The time delay for ICU admission and APACHE-2 score were important risk factors for ICU mortality. These patients should be admitted to the ICU as soon as possible when vital signs are detoriated.

Authors' details

${ }^{1}$ Erciyes University Faculty of Medicine, Internal Medicine, Kayseri, Turkey.

${ }^{2}$ Erciyes University Faculty of Medicine, Internal Medicine Intensive Care Unit, Kayseri, Turkey.

Published: 1 October 2015

doi:10.1186/2197-425X-3-S1-A249

Cite this article as: lleri et al: Evaluation of risk factors for mortality in hematological malignancy patients admitted to intensive care unit. Intensive Care Medicine Experimental 2015 3(Suppl 1):A249.

Submit your manuscript to a SpringerOpen ${ }^{\circ}$ journal and benefit from:

- Convenient online submission

- Rigorous peer review

- Immediate publication on acceptance

- Open access: articles freely available online

- High visibility within the field

- Retaining the copyright to your article

Submit your next manuscript at $\gg$ springeropen.com (c) 2015 Ileri et al.; This is an Open Access article distributed under the terms of the Creative Commons Attribution License (http:// creativecommons.org/licenses/by/4.0), which permits unrestricted use, distribution, and reproduction in any medium, provided the original work is properly cited. 